This is an Accepted Manuscript of an article published by Taylor \& Francis in Lournal of Youth Studies on 24 Jul 2012, available online:

http://www.tandfonline.com/doi/pdf/10.1080/13676261.2012.704986

Published as:

Morrow, Virginia (2013) “Troubling transitions? Young people's experiences of growing up in poverty in rural Andhra Pradesh, India", Journal of Youth Studies 16 (1): 86-100. DOI: $10.1080 / 13676261.2012 .704986$

The article is reproduced in accordance with the self-archiving policies of Taylor \& Francis. 


\title{
Troubling transitions? Young people's experiences of growing up in poverty in rural Andhra Pradesh, India.
}

\author{
Virginia Morrow, Senior Research Officer, Young Lives, Department of International \\ Development, University of Oxford \\ Email address: virginia.morrow@qeh.ox.ac.uk \\ Accepted for publication in Journal of Youth Studies.
}

\begin{abstract}
Global policy attention has begun to focus on young people in developing countries and much of the discourse is framed around notions of 'transition to adulthood' based on the idea that individuals develop in linear ways, separate from family and community. This idea has already been widely critiqued in western contexts. This paper explores the lives of children growing up in rural Andhra Pradesh, India, who are no longer in formal schooling, drawing on data from Young Lives, a longitudinal study of children in four developing countries. Analysis combines descriptive statistics and qualitative longitudinal research. The paper suggests that many of the assumptions underpinning the international discourse fail to match with the realities of young people's everyday lives in rural India. It suggests that young people's obligations to family, combined with a sense of destiny, constrained by gender norms, help to explain their 'transitions' - transitions that are interconnected and depend on each other. The paper concurs that the concept of transition may be useful as a heuristic device, but that it must be used critically and not simply be imposed on contexts that are themselves in transition and in process of rapid social change.
\end{abstract}

\section{Introduction}

Global policy attention is turning to young people, but appears to be dominated by the idea that entry to adulthood is an event hinging mainly upon entry to the labour market (Lloyd 2005, World Bank 2006, Scholvinck and Zelenev 2007, UNICEF 2010). Within developing countries, numerous skills development programmes are in place that are based on the assumption that young people need skills training in order to be attractive to employers, but coverage is not widespread and the value of these initiatives is yet to be assessed. Policy literature relating to youth in developing countries is mainly based upon human capital models derived from economics, combined with a narrow view of linear human development derived from Western developmental psychology, and tends to focus on youth 'at risk', or youth 'as risk'. This combination is in danger of overlooking many factors that impinge on young people's lives, such as class, gender, poverty-status, factors that are underpinned by political economic structures and forms of inequality. The assumption is that, as compulsory schooling is expanded globally, young people with ever-increasing formal qualifications will move seamlessly to work in the labour market, and become independent individuals. The early focus on the transition from school to work in industrialised countries has been roundly 
critiqued within youth studies, as social life has become inherently uncertain, and sophisticated accounts of young people's biographies now inform theorising (Furlong, Woodman and Wyn 2011, Shildrick and MacDonald 2007).

This paper suggests that while in most cultures there is an identifiable notion of adulthood, there is rarely a single moment when the shift from youth to adulthood occurs, and it is problematic to gloss over social or cultural transitions that are fundamentally important at a subjective level. The paper focuses on experiences of young people in rural India who are no longer in school who, from a policy point of view, may be considered to be 'left behind'. The paper contributes to the growing body of global research that problematises youth transitions in situations of poverty, from a range of social science disciplines, including sociology, social anthropology, and social geography (see for example Jeffrey and McDowell 2004, Jeffrey 2010a, Jeffrey and Dyson 2008, Punch 2011, Sommers 2012).

The paper is structured as follows. The next section reviews the literature on youth transitions and briefly describes some alternative conceptualisations. The paper then takes an example from Andhra Pradesh, India, explaining the policy context, then drawing on data from Young Lives, a longitudinal study of children in four developing countries. The paper presents descriptive statistics to illustrate patterns of school leaving, combined with qualitative longitudinal research to develop four case studies, exploring the interconnected themes of school, work, and anticipated marriage. It concludes that childhood and youth need to be understood as relational categories, emphasising young people's connectedness to others, and that while transition may be a heuristic device, the assumptions behind it should be viewed critically.

\section{The trouble with 'transitions'}

A number of recent international policy reports have focussed on youth in developing countries. While these documents have differing priorities and foci (population, labour market, and so on), they all emphasise youth demographics, the importance of qualifications and skills acquisition, and the potential of young people. Policy documents also define what counts as a 'successful' or 'unsuccessful' transition to adulthood (Lloyd 2005). From the World Bank perspective, the key tasks of this age group are to attain economic independence (World Bank 2006, p. 2) and the transitions expected are from school to work, starting a family, developing a healthy lifestyle, and 'exercising citizenship'. Decisions about these transitions can be made 'well' or 'badly'. Starting work 'too early' is seen as preventing 
young people from acquiring the skills to make them attractive to employers (World Bank 2006). Policy recommendations in reports by international organisations focus on individual development, though there is some acknowledgement that family and community relationships may be valued more highly than autonomy in some cultures. There is also acknowledgement that there are widening gaps in young people's experiences, some experiencing progress, while others are 'left behind' (Lloyd 2005, p. 20). In general, these documents take for granted a (Western) normative model of youth as a problematic stage in the life course in advocating a unitary developmental path towards adulthood. Yet even in the West, independence is not an inevitable attribute of adulthood, and individuals are dependent on many institutional bonds (Beck and Beck-Gernsheim 2002), even though young people themselves tend to consider independence a vital part of adulthood (see Arnett's concept of 'emerging adulthood', Arnett 2000). Further, international policy literature generally fails to reflect upon the socio-economic contexts in which young people find themselves, that is, growing up in societies that can be said to be in transition themselves, with rapid social change and increasing modernity, uneven economic development, uncertainty about jobs, and shifting policy contexts, all of which are affected by broader political economic structures.

Assumptions about transitions to adulthood have long been challenged in the youth studies for Western contexts, as young people experience 'fractured' or 'disrupted' transitions (see for example Shildrick and MacDonald 2007). Some writers have suggested that the concept of 'transition' is redundant, because it sets up false dichotomies - between child and adult, school and work, marriage, leaving home, and assumes that young people move straightforwardly from one state to the next, and some question about whether young people will attain adulthood at all (Jeffrey 2010b). Drawing on ideas from Bourdieu (1977) and Johnson-Hanks (2002), Jeffrey (2010b) suggests that the concept of 'vital conjunctures' is a useful alternative to transitions, because it emphasises the uneven challenges that young people encounter, as well as enabling a focus on configurations of structures that are pertinent in specific cases. He argues that this enables comparisons to be made between countries, as well as consideration of the global contexts in which young people are located. Furlong, Woodman and Wyn (2011) propose an approach to the study of youth based on social generations, following Mannheim's classic work (Mannheim 1953, see also Jeffrey 2010a, and Mayall 2002 for childhood). However, these complex theoretical ideas do not appear to be filtering through to policy conceptualisations and documentation, so this paper explores what happens when we retain, and problematise, the concept of transitions as a heuristic 
device (as suggested by Shildrick and MacDonald 2007) for thinking about young people's pathways in developing country contexts.

\section{Young Lives}

This paper draws on data from Young Lives, a study investigating childhood poverty in four countries - Ethiopia, Peru, India (Andhra Pradesh) and Vietnam - over 15 years (2002-2017). The study aims to improve understanding of the causes and consequences of childhood poverty and the role of policies in improving children's life chances. It collects longitudinal data from two cohorts of children in each country: 2,000 children born in 2000-1 (the younger cohort) and 1,000 children born in 1994-5 (the older cohort). The sample is not representative, but pro-poor in that poor rural and urban sites were intentionally oversampled $^{1}$. A survey ${ }^{2}$ is carried out every three years $(2002,2006,2009)$ with the full sample of children and their caregivers, and is complemented by qualitative research $(2007,2008$, 2010) in four communities with a sub-sample of children, their caregivers, and other key figures in the community.

Fieldwork is conducted by local research teams, fluent in local languages. A range of qualitative research methods are used, including one-to-one interviews, group discussions and creative activities (such as drawings and body-mapping) Interviews are conducted in homes, fields, or in village community premises, and are voice recorded, transcribed, and translated. Interviews are structured around specific questions, and last from 30 minutes to 2 hours. Methods are piloted, and research teams work closely to check data quality, translation and to reflect on interpretation. Data are coded by themes, using Atlas.ti qualitative data analysis software. For this paper, a case study approach has been utilised, by examining all interviews with children over successive data collection rounds. Data are divided into different domains such as education, work and aspirations, and creating a narrative for each domain (see www.younglives.org.uk for details of methods, ethics, and analysis).

\footnotetext{
${ }^{1}$ The sample is divided into quintiles (groups of equal size) according to their per capita household expenditure, where the lowest quintile (bottom 20 percent) of families are considered to be the 'poorest' and those in the highest quintile (top 20 percent) the 'least poor'. Household expenditure is considered the most appropriate poverty indicator. It is calculated as the sum of the estimated value (approximated to the past month), of food (bought + home grown + gifts/transfers) and non-food (excluding durables such as furniture, gold jewellery and one-off expenditures). This monthly figure is then divided by household size.

${ }^{2}$ Survey data are publically archived and available via www.esds.ac.uk
} 
The next section briefly introduces the policy context in India in relation to childhood and youth, then draws on data from Young Lives Survey Round 3, conducted in 2009. It presents descriptive statistics relating to children no longer at school. It then presents Young Lives qualitative longitudinal data from two rural sites. Out of 24 Older Cohort children, five (two girls and three boys) were no longer in school when interviewed in 2008. Children selected for analysis are four of these five children. The two girls live in one village, and the two boys in another. (One boy has been omitted because his case is exceptional, see Crivello et al 2011). These proportions of children are reflected in trends from Young Lives survey findings.

It is important to acknowledge some limitations. First, the Young Lives sample is pro-poor, and thus is not representative. Second, by deliberately focusing on young people who are no longer at school, the paper emphasises what might be termed 'traditional' pathways, and while this appears to be a (sizeable) minority, the majority of children are still enrolled in formal school, though many combine school and work. (Future papers will explore their experiences). Thus, it would be wrong to generalise from the cases presented, but the descriptive statistics give some indication of the overall trends related to children's schooling in Andhra Pradesh.

\section{Social policies in India - transitions in dynamic contexts}

In the past decade, India has undergone rapid economic growth, yet the disparities between regions and differing social groups are very stark (Drèze and Sen 2011). In relation to formal schooling, school enrolment has increased markedly. School is compulsory to age 14, and national and state level exams are held at age 15 at the end of $10^{\text {th }}$ Grade. Children who pass the exams are entitled to progress to Secondary Education. The Government of India has introduced a reservation system to prohibit discrimination against children from Scheduled Tribes, Scheduled Castes, and Backward Classes ${ }^{3}$. The policy context is changing rapidly, and currently there are plans to provide universal access to secondary and further education to age 18, under Rashtriya Madhyamik Shiksha Abhiyan, introducing life-skills and vocational training. The Ministry of Rural Development has recently introduced the National Rural Livelihoods Mission, which includes schemes to train young people in skills acquisition

\footnotetext{
${ }^{3}$ Scheduled Castes (SCs) are the lowest in the traditional caste structure and were earlier considered to be 'untouchables'/dalit. SCs have been subjected to discrimination for years and had no access to basic services, including education. Backward Castes or Classes (BCs) are people belonging to a group of castes who are considered to be 'backward' in view of the low level in the caste structure. Scheduled Tribes are indigenous communities, who are traditionally disadvantaged and live in forests and mountainous areas.
} 
under private-public initiatives (Government of India, 2009). The Government is also currently considering banning child labour for all those under 18. The vision of youth promised here is of children staying longer in formal education, in line with the global model being promoted in international policy debates. Finally, in relation to work, much effort has been put into providing social protection for rural poor in the form of guaranteed work. The Mahatma Gandhi National Rural Employment Guarantee Scheme (NREGS), introduced in 2006, guarantees 100 days work a year in public works and land cultivation for a wage of 100 Rs/- a day (Galab et al. 2011).

How many children are no longer in school, and why?

Analysis of longitudinal data shows that school enrolment for the Older Cohort of children has declined from $98 \%$ in Round 1 (age 8), to 90\% in Round 2 (age 12), and further declined by Round 3. Ten percent of children repeated a grade, and $13 \%$ left school between the ages of 12 and 15 (Galab et al. 2011). By 2009, 23\% of the older cohort children ( $n=221$ out of $\mathrm{n}=976$, aged 15-16) were no longer enrolled in formal education. Children from Scheduled Castes and Scheduled Tribes were twice as likely to have left school. More girls have left school than boys between Round 2 and Round 3. Table 1 below presents data disaggregated according to gender, caste, location and whether they are working for pay. There are higher rates of school leaving amongst young people in rural areas, in poorer households, and among girls. 
Table 1: Young Lives, Andhra Pradesh, India, Older Cohort children no longer enrolled in school, 2009, by gender, caste and location

\begin{tabular}{|l|r|r|r|}
\hline & Older Cohort (n) & Not Enrolled (n) & Not Enrolled (\%) \\
\hline Whole Sample & 976 & 221 & $22.5 \%$ \\
\hline Girls & 498 & 129 & $26 \%$ \\
\hline Boys & 478 & 92 & $19 \%$ \\
\hline Scheduled Castes & 200 & 49 & $24.5 \%$ \\
\hline Schedules Tribes & 96 & 24 & $25 \%$ \\
\hline Backward Castes & 493 & 115 & $18 \%$ \\
\hline Other castes & 187 & 33 & $15 \%$ \\
\hline Urban & 248 & 38 & $25 \%$ \\
\hline Rural & 728 & 183 & $55 \%$ \\
\hline Working for pay & 273 & 150 & $10 \%$ \\
\hline $\begin{array}{l}\text { Not working for } \\
\text { pay }\end{array}$ & 702 & 71 & \\
\hline
\end{tabular}

Table 2 presents analysis of survey data the primary reason that young people give for no longer being enrolled in school. 
Table 2: Main reasons given by children for not being enrolled in school, Young Lives, Older Cohort (\%)

\begin{tabular}{|l|r|r|r|r|r|}
\hline Main Reason for not being enrolled (\%) & \multicolumn{1}{|c|}{ Boys } & \multicolumn{1}{|l}{ Girls } & Urban & Rural & Total \\
\hline $\begin{array}{l}\text { Cost (fees, books, supplies, transport, } \\
\text { uniform) }\end{array}$ & 2.2 & 7.0 & 10.8 & 3.8 & 5.0 \\
\hline Transport (lack of transport, safety) & 2.2 & 5.4 & 0.0 & 4.9 & 4.1 \\
\hline Child did not want to go, not interested & 29.7 & 6.2 & 10.8 & 16.9 & 15.9 \\
\hline $\begin{array}{l}\text { Banned from school (behaviour, } \\
\text { prolonged absence) }\end{array}$ & 11.0 & 2.3 & 13.5 & 4.4 & 5.9 \\
\hline Bullying/ Ill treatment (peers, teachers) & 2.2 & 1.6 & 0.0 & 2.2 & 1.8 \\
\hline $\begin{array}{l}\text { Needed at home(agricultural and/or } \\
\text { domestic work, care for siblings) }\end{array}$ & 5.5 & 19.4 & 0.0 & 16.4 & 13.6 \\
\hline Had to do paid work to earn money & 20.9 & 11.6 & 24.3 & 13.7 & 15.5 \\
\hline Illness, injury & 2.2 & 4.7 & 8.1 & 2.7 & 3.6 \\
\hline Family member ill/disabled/elderly & 5.5 & 3.9 & 2.7 & 4.9 & 4.6 \\
\hline Family issues & 3.3 & 2.3 & 0.0 & 3.3 & 2.7 \\
\hline Festivals & 1.1 & 0.8 & 0.0 & 1.1 & 0.9 \\
\hline Migration with parents & 0.0 & 7.0 & 5.4 & 3.8 & 4.1 \\
\hline Other & 14.3 & 25.6 & 18.9 & 21.3 & 20.9 \\
\hline Not known or not applicable & 0.0 & 2.3 & 5.4 & 0.6 & 1.4 \\
\hline Total & 100.0 & 100.0 & 100.0 & 100.0 \\
\hline $\begin{array}{l}\text { Total number of children (not } \\
\text { enrolled) }\end{array}$ & & 38 & 185 & 223 \\
\hline
\end{tabular}

Table 2 shows that boys leave school for a number of reasons. Nearly 30 per cent of the boys left school for 'school-related reasons' (did not want to go to school/ not interested qualitative data discussed below shed some light on the reasons behind this). Twenty per cent left because they work for pay, and $5.5 \%$ because they were needed for domestic/agricultural work. Girls are more likely to have left school because a family member is ill, or they are doing domestic and/or agricultural work (16.4\%). The next section 
draws on longitudinal qualitative data to explore young people's experiences behind these statistics.

\section{Case study children}

Latha ${ }^{4}$ and Bhavana are both Hindu girls living in Katur, a poor rural community in Rayalaseema region of Andhra Pradesh. The area is drought-prone. During the nonagricultural season, most inhabitants attend to work provided under NREGS, and some families also migrate to nearby villages, towns and cities in search of work. There is a government primary school up to Standard 7 (that is, up to age 14), and children continue at a high school approximately three kilometres away, along a deserted route. This means that many girls discontinue after primary school. Some changes have been observed within the community, including slightly improved facilities in the primary school. In 2010, the community was facing a severe drought, with poor groundnut yields. Bhavana's father died when she was about 9 years old, and she lives with her mother, brother and sister-in-law. The family own two acres of land, plus one acre of 'dry' land. Latha lives with her parents and older brother, who had married by 2010, when Latha's sister-in-law joined the household. Latha and her family work as daily wage labourers as well as cultivating their two acres of land.

Subbaiah and Ranadeep both live in Poompuhar, a very poor rural community in southern Telangana region of Andhra Pradesh. The major occupations are in agriculture, and daily wage labour. Children are involved in cotton seed pollination work which means they miss school for two to three months each year, though this declined between 2007 and 2008 (Morrow and Vennam 2010). A new local secondary school has opened, and by 2010 children were attending school regularly. Seasonal migration (February/May until June/July) was common, but the introduction of NREGS means that wages have risen and there is plenty of work in public works (a railway track, and canal work) as well as subcontract work on small farms. Both Subbaiah and Ranadeep left school after Grade 10. Subbaiah is the only son, and has three sisters, one older, who was married by 2010. Ranadeep has an older sister, who married by 2010 . The family farm 10 acres of land, growing paddy and cotton.

\footnotetext{
${ }^{4}$ All names of people and places are pseudonyms.
} 
All four young people are from Backward Castes, three are in the third poverty quintile, and Bhavana is in the least poor quintile. For children in both communities, changes in social status are marked by ceremonies at various points during the life-cycle. Further, religious celebrations are symbolically important, and are described as a source of joy, because they enable extended families to come together for several days to share festivities, buy new clothes, eat together, outside the remit of this paper to explore.

\section{Interconnecting school, work, marriage}

As noted, research on youth transitions in industrialised countries has tended to conceptualise school and work as separate domains, with the assumption being that children do not undertake work (broadly defined) while they are at school. In developing countries, and especially in rural areas, despite increased school enrolment, children's (paid and unpaid) work is still expected as part of the family unit and large numbers of children combine school and work, so the two fields of activity are not easily separated. Children's formal schooling may be negatively affected by working. At the same time, children may chose to work, when schooling is of poor quality, and poverty makes their work a necessity for survival in labour intensive activities like subsistence and market farming. There are also concerns (from parents and children) about whether formal education will deliver what it promises, and the need for children to be skilled in agricultural work is a viable if undesirable alternative (see Morrow and Vennam 2012). Furthermore, the key marker of adulthood in poor communities in India for men and women is marriage (see George 2002). Working 'well' during childhood is viewed as important for the future, especially for girls (see also Dyson 2008). The three spheres, of school, work and anticipated marriage, are intertwined, and experience of each affects the other.

\section{School experiences}

As Table 1 demonstrates, children in rural areas are more likely to have left school by 2009 , and $26 \%$ of girls were no longer in school. Bhavana and Latha were not at school when first interviewed aged 12 in 2007. Bhavana had stopped school after Second Grade (age seven), and hardly mentions school. By 2010, she says 'I used to think it would have been better if I had been to school', but now 'it is better if we learn to work in the fields', and her mother told her that if she learns to work well, her future in-laws will look after her well. Latha stopped school after the $7^{\text {th }}$ class (aged 10), and when first interviewed in 2007, aged 13, she 
talked about how she enjoyed fetching water for the household, and doing rangoli. She had wanted to continue to secondary school but the distance to school meant she did not: "we are supposed to go to school in [nearby village]... It is difficult to go to, we have to walk to go to school. So that is the reason we stopped'. She said 'I would like to study but they [parents] stopped me... learn work, said my father and mother... however much I told them, they didn't listen to my words'. When asked how she felt when she went to school, she said 'I used to feel so happy', though she does mention how she was afraid of teachers, 'when I didn't complete my homework, I was scared that the teacher might beat me'. She reflected on her childhood: 'then there was little work, I was enjoying [life] a lot with my friends. Now there is nothing... no going anywhere. Now, there is no joy'. She compared herself to her friends who had stayed at school, saying that

We ask each other 'how are you?', I tell them 'you are better off studying well in the school'... I say this, then they will say 'you are better off, you stay nicely at home. We have to go to school every day' (smiling)

However, when asked how she felt in comparison to school-going children in general, she said she felt 'nothing... because everything is god given'.

Within the Young Lives sample, boys are more likely than girls to remain enrolled in school for longer (Table 1). Subbaiah had left school having failed his $10^{\text {th }}$ grade exams. When interviewed in 2010, he talked about how he felt about this:

I knew how well my parents brought me up, but I didn't live up to their expectations, so I felt bad... they never used to let me do any work, they just used to tell me to go to school and study well.

He described how his mother tells him her problems: 'I feel very sad, I feel I have to take care of her well.... I will see to it that she never faces any problems'. He also describes helping his younger sisters with homework. He talks about returning to his studies: 'I need Government help to tenth class,... If I join a Government college, all the facilities are free, I need not pay anything, but if I join a private college I have to pay for everything. We only get money if we get good crops'.

Ranadeep expressed a similar sense of disappointment. In 2008, he had described his parents 'making' him do farm work (cotton pollination work and irrigation) which he did not like. If he missed school, the teachers would scold him. He talked about his ambition to migrate and

\footnotetext{
${ }^{5}$ Rangoli are patterns made with powder every morning in front of the house. Being able to do rangoli is an assessment of a girl's ability to undertake household work.
} 
open his own business, running a small shop. He wanted to study well to get a good job, and was planning to continue intermediate education, hoping to attend a college in a nearby town, staying with his paternal uncle. By 2010, like his friend Subbaiah, he had left school after failing Maths, and was now farming. He explained that all his five friends had failed. He applied to re-take the supplementary exam. If he passes, he will go to college. He talked about how when he was studying in $10^{\text {th }}$ class, there were 43 students, of whom 23 have moved up to intermediate college. He felt his friends who had succeeded and are now at college 'look at me very cheaply' [look down on him] and said 'I am hurt because I am not there with my friends'. Ranadeep explained that he, and other children in the community, failed their exams because they attended school irregularly, trying to combine school with work. In the past, his uncle told his parents not to make him work on the land, but

my parents never listened to him... there is nobody to work in the fields, and there is no labour..., and we need to pay Rs100/- as wages every day, and we were not able to afford it, so they stopped me from going to school. [My parents] told me I need to do both work and studies.

This led to family arguments, because his father blamed his mother for sending him to work:

My father knows, he has studied so he knows the importance of 10th class, but my mother is not educated... so she does not know... she says we will not get jobs even if we study, so she will tell us to come to the fields and work. I told her $10^{\text {th }}$ class is important, and I will be a waste if I don't complete my $10^{\text {th }}$ class, .... My mother never listened. So my father took me to the fields to work, they stopped me from going to school for a month. During that time they [fellow schoolmates] covered most of the lessons. Then I used to borrow the notes from my friends in the night, and used to study, and used to say the answers when the teachers asked me. I used to ask my friends what they learned in school that day, and used to update myself.... my friends helped me a lot.

This example illustrates the conflict and negotiation taking place within households (see also Punch, 2007). Ranadeep is balancing his aspirations as an individual with the household's needs. He lacked the social power to resist the moral imperative to help his family, but the overarching constraint is economic circumstances.

Work

Table 2 shows $26.4 \%$ of boys and $30 \%$ of girls had left school because they were needed for domestic, agricultural, or other paid work. When interviewed in 2007, Bhavana's time was taken up with work, and she described how at domestic work 'is one type of work, if I go to the fields, that is another type of work'. She migrates with family members to Mumbai for 6 
months each year, where an uncle finds them work, but her role in this has changed over the years. When first interviewed in 2007, at the age of 13 , she was responsible for cooking while family members worked in construction. By 2010, aged 16, she was working in construction and road building with her brother and sister-in-law, as well as undertaking seasonal agricultural work, harvesting groundnut, transplanting and harvesting paddy. She also works at a village $4 \mathrm{~km}$ away, on NREGS work, carrying bricks, stones, cement and water. This is hard work, and she gets blisters on her hands. Agricultural work is also heavy work. However, she says the family's condition '... is improving with becoming older.... we are going to work. We give money to our mother - we won't take even a rupee... We went to Mumbai and gave Rs. 20,000 to my mother... my mother bought a TV and fan ...' She likes harvesting groundnuts because 'we go with people, happily-it would be better if we talk and do the work'. She works because her household is

in a very difficult condition... I have to go wherever the work is available ... I am not lucky like [other girls of my age] ... though I am the only girl of the family still I have to do a lot of work.

Bhavana explained: 'One must earn a good name among people.... "she works very well" they should feel like that'. She also described the work in Mumbai, throwing and catching baskets of wet cement, laying concrete. This was hard at first, 'it was very difficult to hold the baskets' but she got used to it. It was important to learn how to work well, to earn goodwill: 'if we do the work well, they call us for the work... it would be better if you get such a name... we lose respect ... if we don't work well'. She felt this too with groundnut harvesting, 'we lose respect if we lag behind'. When asked to compare her life to other girls (who don’t work), Bhavana says:

Some people work like donkeys... but they think about people who don't work. They feel those people are doing well without much work. Whereas we are to [have to] work. We feel like that.

Latha also described her work, her household conditions, and her expectations. The family land is not irrigated. Poor crops lead to borrowing money from lenders, and income from a good crop is used for repaying loans. Latha described being involved in NREGS work. She earns Rs.100/- per day and she spends some of this on saris and bindis. She was happy doing NREGS works because (like Bhavana during the harvest) she is in the company of others whereas she is often alone or with family members when she is working on the family land. 
Table 2 shows that boys are more likely to have left school in order to enter paid work than girls, though more children report unpaid work in rural areas than urban. Young people are more likely to leave school to work in urban areas (24.3\%) compared to rural areas $(13.7 \%)$. When interviewed in 2008, age 15, Subbaiah described doing some farm work for his family while at school, taking the cattle to graze, harnessing buffalo, and irrigation work, though the family had recently appointed a boy to graze the cattle. In 2010, he describes spending all his time grazing cattle, he has learned to plough, and insists that he likes the work, but it is not as hard as work his friends do, and did in the past, in cotton pollination work and irrigation. Ranadeep had experienced the conflict between school and agricultural work during his schooldays, and felt that working was the explanation for his failure, though he felt concern for his mother, and helped her by fetching water. By 2010, he was working full-time in agricultural work, irrigation, grazing oxen, cutting firewood. Both boys mentioned destiny as an explanation for what has happened to them. When asked about his aspirations in 2010, Subbaiah said: 'I want to become a doctor but I don't know whether it is possible or not'. The interviewer asks him: 'Why do you have a doubt'? Subbaiah explained: 'We can't predict a thing, that is why'. Similarly, Ranadeep described how his friend Prahalad, who had also failed Grade 10 exams, said that 'in our fate it is written that we must only do agriculture/[be farmers]. There is no way we can go to college. He also felt bad, and told me this'.

By 2010, Ranadeep had abandoned his plan to open a shop. He didn't want to tell his family. He explained 'I wanted to do it on my own...I dropped the idea because I never had the money'. He talked about family money problems, explaining that the household needs to pay for pesticides, fertilizers and wages, which meant that he could not ask for financial assistance: he said: 'For that only they spend, and nothing else... what will they spend on me?... I know they are struggling in the house, so how will I ask?' He also described a recent crop failure - 'we need to repay [cotton seed supplier] - we have to pay him from our pocket, since the crops have failed'.

For Ranadeep and Subbaiah, then, vital conjunctures occurred when they failed Grade 10 exams, when circumstances including lack of availability of wage labour on family farms (not least because local wages had increased because of NREGS), as well as difficulties in trying to combine working with studies had combined to prevent them succeeding. However, boys are also disadvantaged by family indebtedness and moral imperatives to help their families. Ranadeep's mother seems to have over-ridden his father's views that he should go 
to school and not work, which challenges (gendered) assumptions about who holds power within families, though family members often make decisions and have responsibilities for different spheres of social life. Notions of transition from school to work do not apply here these young people are already part of society, productive and responsible, within their households. They risk being blamed for their own failure, when it is the circumstances in which they find themselves that constrain them. The boys' 'failure' in particular seems acutely felt. The invocation of fate is a way of making sense of what has happened.

\section{In anticipation of marriage}

Marriage defines adulthood amongst poor rural communities in India, and the case study children were all preoccupied with anticipated marriage. Thirteen girls in the Young Lives sample were already married by 2009, 12 of them in rural areas (Galab et al. 2011). Powerful gender norms operate as to how girls are expected to behave and what makes a 'good' wife. Even when first interviewed at age 12, Bhavana and Latha described learning to work 'properly' - whether housework or in the fields - so they avoid problems with in-laws later on. In 2010, Bhavana expected she will marry in the next three years, and foresees difficulties with her in-laws. It is important for her to learn how to work well, she said, because

by the time we go to our husband's house, we must have learnt all these things... if we don't know these works... they might say "what work do you know? What work have your parents taught you?"... so we have to learn now.

In 2010, Latha said she does not want to marry, explaining that she had some freedom, but anticipates being constrained when she marries: 'As long as you are in your parental home, you do and live as you like. You can't be like that when you go to your in-laws... we have to listen to them. It will be like that'.

For Latha and Bhavana, then, work during childhood is part of their preparation for marriage. For these two girls, vital conjunctures have occurred when they left school at relatively young ages. This highlights the importance of processes of change that fall outside conventional assumptions about biographical transitions, which might be assumed to be when they get married and leave their parental homes. However, Latha expressed some attempt to negotiate her future, because she says she does not want to marry, nor continue in school. Girls face a number of social risks, related to the circumstances of household, the protection of daughters, and the importance of 'reputation'. Latha's case also challenges the assumption that girls are 
'forced' to drop out of school to marry. Poverty-related factors have meant that these two girls are no longer in school, and marriage may be their only route to a secure future.

Boys too described their future marriages, as well as their sisters' future marriages, because they are preoccupied with supporting their families to pay for their sisters' dowries. The educational background and status of future wives is also a concern. Both Ranadeep and Subbaian expressed the view that the girls they marry should be less educated than they are. Subbaiah said

What my mother says is the girl whom I marry must treat the guests who come home with respect and affection. In villages, why do we need her to be educated? If she is not educated, it will be fine.

Ranadeep talked about the characteristics of the girl he will marry. His parents will decide when he will marry, but (like Subbaiah) he described how his wife will need to be either equal to him, or educated to a lower level. He talked at length about dowry payments. If he has a good job, his family can ask for a bigger payment: 'they will feel I will take care of the girl well, so they will give, but if I am farming, who will give? They will not give.' Farming does not enhance his marriage prospects.

In summary, for these young people who are no longer at school, social norms remain conservative. While boys may have greater responsibility for family and therefore greater expectations that they will take advantage of opportunities, they may also have the potential to be more mobile, socially and economically. However, patriarchy remains important not just for constraining girls, but also for boys, in that they too seem to not want to break the traditional cycle of wanting to marry a girl 'less educated' than them, also revealing the gender bias prevalent within Indian families (see Pells 2010, Boyden and Crivello 2011). Young people continuing in secondary and further education have differing values and ambitions, and this will be explored in further papers.

\section{Discussion}

Analysis reveals a complex picture of rural young people's lives, in which interdependence of generations begins with children contributing to household livelihoods at young ages. Qualitative longitudinal research enables survey findings to be explored in context, and we can track the changing experiences in detail. There appears to be a moral economy of intricate connections between material and social values within the context of kinship, and the 'intergenerational mutuality' that is fostered, and this sits uneasily with dominant 
approaches to 'youth' that emphasise the 'transition to (independent) adulthood'. As the cases suggest, these young people's pathways are structured by powerful norms. For the boys, it could be argued that vital conjunctures consist of a combination of household economic circumstances and the timing of specific moments in the life-course. Formal schooling has raised expectations, and they feel they should aspire to be (like Subbaiah) a doctor, yet they remain as farmers. In the case of Ranadeep, his ambition has been thwarted by circumstances.

Further, young people are acutely aware of family indebtedness, and they are important actors in family processes attempting to deal with debt. This shapes young people's close relationships, their expectations, and the realities of their daily endeavours. Children described numerous work-related tasks. However, in policy terms, the skills they learn through the experience of work are never seen as useful in human capital formulations of the transition to adulthood (Jones and Chant 2009). Indeed, working during childhood is seen as detrimental to children's outcomes - 'many adolescents and young children .....are engaged in adult activities such as labour, marriage, primary caregiving... assuming these roles, in effect, robs them of their childhood and adolescence' (UNICEF 2010, p. 10). The idea that formal qualifications are needed to prepare children for work is out of kilter with the realities of these young people's daily lives.

The conceptualisation of transitions to adulthood evident in policy debates did not fit with the accounts from young people. The dichotomy between school and work, as noted, is problematic enough in developed countries, but in rural Andhra Pradesh, it does not apply. What exactly were these young people transiting from, and to? All four children worked during their childhoods, so work was not new to them, though the work has changed in intensity as they have taken on more responsibilities and become acutely aware of their families' financial situations. Work in and of itself was not a 'marker' of adulthood, and notions of independence and autonomy are not relevant. Further, there are broader societal 'transitions' relating to shifting social policies that affect them (beyond the obvious influence of formal schooling). NREGS is reported by Ranadeep as the reason that his parents can no longer afford wage labour, so he undertook the necessary work himself (though, in general, NREGS has positive effects for wage labourers, see DFID 2011). Conversely, for Latha, involvement in NREGS means that she can earn a fixed wage, and spend money. Young people experience various social changes, and not necessarily in a linear fashion. The socio-political contexts in which they are located are also dynamic - economic transitions that 
may bring opportunities, but also social risks. The emphasis in global policies on increasing school enrolment needs to be balanced by attention not only to children's relationships to school, but also to the appropriateness of skills training in the context of opportunities for work and specific (formal) labour markets. The emphasis on adolescence as 'preparation for participation in adulthood', may be misplaced.

In conclusion, transition may be useful as a heuristic device but not as an end in itself, and it needs to be seen critically. As Jeffrey and McDowell (2004, p. 137) noted nearly a decade ago, 'it is a cruel irony that, as Western ideals have been exported outside Euro-America, it has become increasingly difficult for young people in Third World settings to emulate these ideals'. Young people in situations of poverty in developing countries are on varying trajectories, and the four children described here might be considered to be on 'traditional' pathways, but these are devalued in the policy discourse - they would be considered 'left behind', 'robbed' of their childhoods. We need further theoretical refinement and a nuanced view to encompass the heterogeneity of children's experiences, a view that contextualises children's experiences in historical and poverty circumstances, and a view that does not inadvertently privilege or reify certain trajectories over others. Finally, we need a view that respects the worth and dignity of young people who remain where they started, and does not make them feel 'left behind' and 'a waste'.

\section{References}

Arnett, J., 2000. Emerging adulthood. A theory of development from the late teens through the twenties. American Psychologist, 55, 5, 469-480.

Beck, U., and Beck-Gernsheim, E., 2002. Individualisation: institutionalised individualism and its social and political consequences. London: Sage.

Bourdieu, P., 1977. Outline of a theory of practice. Cambridge: CUP.

Boyden, J. and Crivello, G., 2011. Political economy, perception and social change as mediators of childhood risk in Andhra Pradesh. In J. Boyden, and M. Bourdillon, eds. Childhood poverty: multidisciplinary approaches in Young Lives. London: Palgrave.

DFID (Department for International Development), 2011. Cash transfers. Evidence paper. Policy Division. Available from: www.dfid.gov.uk [Accessed 18 July 2011].

Drèze, J., and Sen, A., 2011. Putting growth in its place. Outlook, India. Available from www.outlookindia.com. [Accessed 14 Feburary 2012].

Dyson, J., 2010. Friendship in practice: girls' work in the Indian Himalayas. American ethnologist, 37 (3), 482-498. 
Furlong, A., Woodman, D., and Wyn, J., 2011. Changing times, changing perspectives: reconciling 'transition' and 'cultural' perspectives on youth and young adulthood. Journal of sociology, 47 (4), 355-370.

Galab S., Kumar, V., Reddy, P., Singh, R., and Vennam, U., 2011. The impact of growth on childhood poverty in Andhra Pradesh, India. Oxford: Young Lives

George, A., 2002. Embodying identity through heterosexual sexuality - newly married adolescent women in India. Culture, health and sexuality, 4 (2), 207-222.

Government of India (2009) National Rural Livelihood Mission: A fresh lease of life for the rural people living below the poverty line.

http://pib.nic.in/newsite/erelease.aspx?relid=52423 accessed 23 May 2011.

Jeffrey, C., 2010a. Timepass: waiting, micropolitics and the Indian middle class. Stanford, CA: Stanford University Press.

Jeffrey, C., 2010b. Geographies of children and youth I: eroding maps of life. Progress in human geography, 34 (4), 496-505.

Jeffrey, C. and Dyson, J., 2008. Telling young lives. Portraits of global youth. Philadelphia, PA: Temple University Press.

Jeffrey, C. and McDowell, L., 2004. Youth in a comparative perspective. Global change, local lives. Youth and society, 36, 131-142.

Johnson-Hanks, J., 2002. On the limits of life stages in ethnography: toward a theory of vital conjunctures. American anthropologist, 104 (3), 865-880.

Jones, G. and Chant, S., 2009. Globalising initiatives for gender equality and poverty reduction: exploring 'failure' with reference to education and work among urban youth in The Gambia and Ghana. Geoforum, 40, 184-196.

Lloyd, C., ed. 2005. Growing up global. The changing transitions to adulthood in developing countries. Washington DC: National Academies Press.

Mannheim, K., 1953. The Problem of Generations, in P. Kecskemeti, ed. Essays on the Sociology of Knowledge by Karl Mannheim New York: Routledge \& Kegan Paul.

Mayall, B., 2002. Towards a sociology for childhood. Buckingham: Open University Press.

Morrow, V., and Vennam, U., 2010. Combining work and school: the dynamics of girls' involvement in agricultural work in Andhra Pradesh, India. Children \& Society, 24, 304-314.

Morrow, V., and Vennam, U., 2012. Children's responses to risk in agricultural work in Andhra Pradesh, India. Development in Practice, 22, 4, 549-561.

Pells, K., 2010. Inequalities, life chances and gender. Oxford: Young Lives.

Punch, S., 2011. Young Migrant Livelihoods: Constrained and Negotiated Interdependencies in Bolivia, Migration and Family Relationships ESRC Seminar, Inverness: University of Highlands and Islands, <http://www.crfr.ac.uk/events/esrcseminars.html>

Punch, S., 2007. Generational power relations in Bolivia, in R.Panelli, S. Punch and E. Robson, eds. Global perspectives on rural childhood and youth. London: Routledge 
Scholvinck, J. and Zelenev, S., 2007. World Youth Report: young people's transition to adulthood: progress and challenges. New York: UN.

Shildrick, T. and MacDonald, R., 2007. Biographies of exclusion: poor work and poor transitions. International journal of lifelong education, 26 (5), 589-604.

Sommers, M., 2012. Stuck: Rwandan youth and the struggle for adulthood. Athens, Georgia: University of Georgia Press.

UN, 1995. World Programme of Action for Youth to the Year 2000 and beyond. Resolution. New York: UN. www.social.un.org. [Accessed 6 July 2011].

UNICEF, 2010. Adolescence. An age of opportunity. The state of the world's children report 2011. New York: UNICEF.

World Bank, 2006. Development and the next generation. World development report 2007. Washington, DC: World Bank.

\section{Acknowledgements}

Thanks to Young Lives children, families and other community members, and the Qualitative research team in Tirupati; Patricia Espinoza and Emma Wilson for research assistance, and Jo Boyden, Gina Crivello, Paul Dornan, Renu Singh, Kirrily Pells, and Uma Vennam who provided comments on earlier drafts. A version of this paper was presented at an ESRCfunded seminar: Exploring Children's Relationships across Majority and Minority Worlds, Youth transitions to adulthood, April 2011. Young Lives is funded by the UK Department for International Development (DFID). The views expressed here are solely those of the author. 
